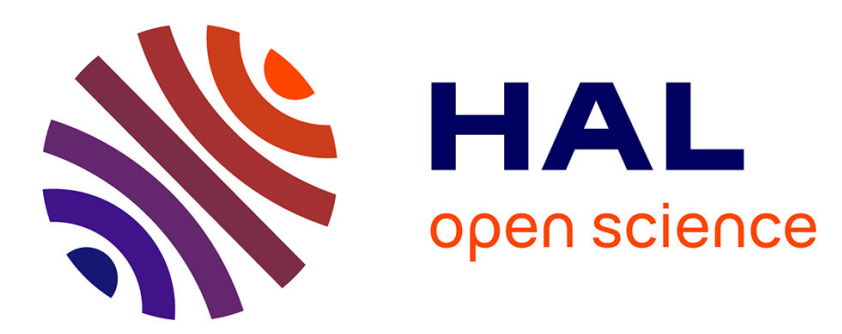

\title{
Fossil fuel biomarkers in plant waxes as pollution parameters
}

\author{
Carine Bryselbout, Pascale Henner, Eric Lichtfouse
}

\section{To cite this version:}

Carine Bryselbout, Pascale Henner, Eric Lichtfouse. Fossil fuel biomarkers in plant waxes as pollution parameters. Science of the Total Environment, 1998, 222 (3), pp.201-204. 10.1016/S00489697(98)00297-6 . hal-00193351

\section{HAL Id: hal-00193351 \\ https://hal.science/hal-00193351}

Submitted on 3 Dec 2007

HAL is a multi-disciplinary open access archive for the deposit and dissemination of scientific research documents, whether they are published or not. The documents may come from teaching and research institutions in France or abroad, or from public or private research centers.
L'archive ouverte pluridisciplinaire HAL, est destinée au dépôt et à la diffusion de documents scientifiques de niveau recherche, publiés ou non, émanant des établissements d'enseignement et de recherche français ou étrangers, des laboratoires publics ou privés. 
Revised version

The Science of the Total Environment 222, 201-204, 1998.

doi: 10.1016/S0048-9697(98)00297-6

Correspondence: Dr. Eric Lichtfouse, INRA-CMSE-PME, 17, rue Sully, 21000 Dijon, France

Eric.Lichtfouse@dijon.inra.fr

\title{
Fossil fuel biomarkers in plant waxes as pollution parameters
}

\author{
Carine BRYSELBOUT, Pascale HENNER and Éric LICHTFOUSE*
}

Laboratoire Sols et Environnement, INRA/ENSAIA-INPL, BP 172, 54505 Vandoeuvre-Lès-Nancy, France.

\begin{abstract}
Hopane and sterane derivatives typical of highly mature sedimentary organic matter, e.g. petroleum, have been identified in several plant species growing near Nancy, France. Analyses of plant waxes by gas chromatography-mass spectrometry over a restricted mass interval (m/z 185195) allows definition of pollution parameters based on the relative concentration of fossil hopanes versus modern plant $n$-alkanes. Indeed, such parameters are higher for Pinus nigra growing along a high traffic highway than for Pinus nigra growing in a less polluted suburb area. Molecular pollution parameters based on fossil molecules are thus promising tools for measuring the extent of fossil fuel input into plant and food.
\end{abstract}

Keywords : plant wax $n$-alkane, petroleum, hopane, sterane, pollution

\section{INTRODUCTION}

After deposition at the bottom of lakes and seas, organic debris is slowly buried over geological time. With increasing time of burial, biogenic molecules, e.g. bacterial hopanols, undergo chemical alteration under the effect of biodegradation, mineral catalysis, increasing pressure and temperature to yield derivatives, e.g. fossil hopanes [1-4]. Then, these molecular fossils may reenter the biosphere by natural and anthropogenic processes such as sediment uplift and petroleum exploration. Thus, the occurrence of molecular fossils in soils, mud, recent sediments and airborne particulate matter can be used to assess an input of petroleum products [5-9]. Here we report the first identification of fossil fuel biomarkers in plants.

\section{EXPERIMENTAL}

Full experimental procedure and data will be reported elsewhere. Aerial plant parts (leaves, needles) were sampled on march 25, 1998 at two locations at Vandoeuvre-Lès-Nancy, a suburb of Nancy : 1) highly contaminated samples growing on soils at about $3 \mathrm{~m}$ from a high traffic highway, and 2) less contaminated samples growing on urban soils of the Brabois area near the Agronomy school. Plant species include Pinus nigra (Austrian pine), Taraxacum obovatum (dandelion), Viola silvestris (violet), Primula auricula (primrose) and Poa trivialis L. (meadow grass). Fossil fuel biomarkers were identified by comparison of their chromatographic and mass spectrometric behaviour with data from a petroleum fraction from the Paris basin and from a petroleum fraction kindly provided by Dr. P. Adam (Strasbourg University).

\footnotetext{
* Author for correspondence <lichtfouse@ensaia.u-nancy.fr>
} 
Cuticular waxes were extracted from ground dried samples $\left(150 \mathrm{mg}\right.$ ) by elution of $\mathrm{CH}_{2} \mathrm{Cl}_{2}$ over a modified Pasteur pipette [10]. The extracts were fractionated into alkane and aromatic fractions by elution with $n$-pentane and $n$-pentane- $\mathrm{CH}_{2} \mathrm{Cl}_{2} 65 / 35 \mathrm{v} / \mathrm{v}$ on a modified Pasteur pipette loaded with silica gel. Alkane fractions were analysed with a Varian Star 3400 gas chromatograph coupled to a Saturn 2000 ion trap mass spectrometer. Conditions: helium pressure 11 psi; on column injector; $30 \mathrm{~m}$ x $0.25 \mathrm{~mm}$ i.d. fused silica gel column coated with 5\%phenyl-, $95 \%$ methylpolysiloxane phase $\left(0.25 \mu \mathrm{m}\right.$ thickness); oven temperature : $30^{\circ} \mathrm{C}$ isothermal $1 \mathrm{~min}$, $30-150^{\circ} \mathrm{C}$ at $15.6^{\circ} / \mathrm{min}, 150-310^{\circ} \mathrm{C}$ at $3^{\circ} / \mathrm{min}$ then $310^{\circ} \mathrm{C}$ isothermal $30 \mathrm{~min}$; EI $70 \mathrm{eV}$. For each alkane fraction, one injection was performed scanning in the $\mathrm{m} / \mathrm{z}$ 187-195 range for hopane derivatives and $n$-alkanes, and another injection was performed scanning in the $\mathrm{m} / \mathrm{z} 213-221$ range for sterane derivatives and $n$-alkanes. Identification was conducted by co-elution of pure $n$ alkanes and comparison of chromatographic characteristics with the petroleum sample and with the literature [8,11-12]. Maturity parameters based on relative concentration were calculated by area integration from the $\mathrm{m} / \mathrm{z} 191$ chromatogram.

\section{RESULTS AND DISCUSSION}

\section{Fossil fuel biomarkers}

Several plant species were sampled in both high- and medium-contaminated areas near Nancy, France. Cuticular waxes were extracted then fractionated into alkane and aromatic fractions. Since fossil fuels occur only at low concentrations relative to plant wax $n$-alkanes, gas chromatophic-mass spectrometric analysis of alkane fractions was optimised by scanning over a limited interval, e.g. m/z 187-195 (Fig. 1). Selective detection was achieved using reconstructed ion currents at 194 amu for $n$-alkanes and 191 amu for hopanes (Fig. 2), thus giving ion current responses in the same order of magnitude for both chemical classes. Indeed, the ion current at 194 allowed to detect selectively $n$-alkanes, though the molecular mechanism leading to this fragment is unknown. Other typical $n$-alkane fragments may be used such as m/z 183 and 197. On the other hand, the relative concentration of $n$-alkanes and hopanes can be measured using using $\mathrm{m} / \mathrm{z} 191$ because this ion current shows both classes of molecules.

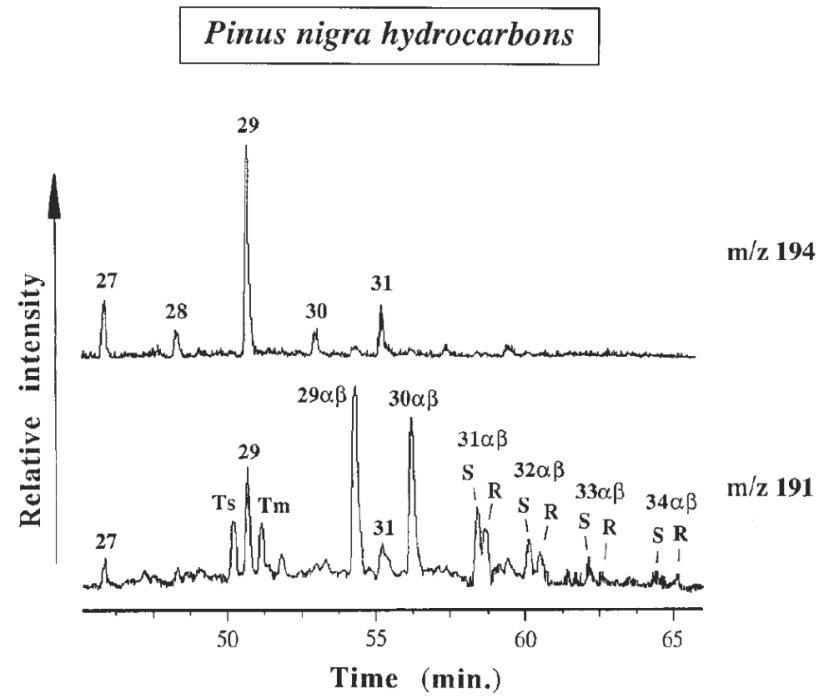

Figure 1. Plant wax $n$-alkanes and fossil fuel hopanes occurring in pine located near a highway. Gas chromatography-mass spectrometry : 187-195 amu scan range. Numbers refer to $n$-alkane carbons. Ts: $18 \alpha-$ 22,29,30-trisnorneohopane; Tm: 17 $\alpha$-22,29,30-trisnorhopane; 29-34 $\alpha \beta$ : 17 $\alpha, 21 \beta$-hopanes. S and R refer to hopane configuration at position 22. 

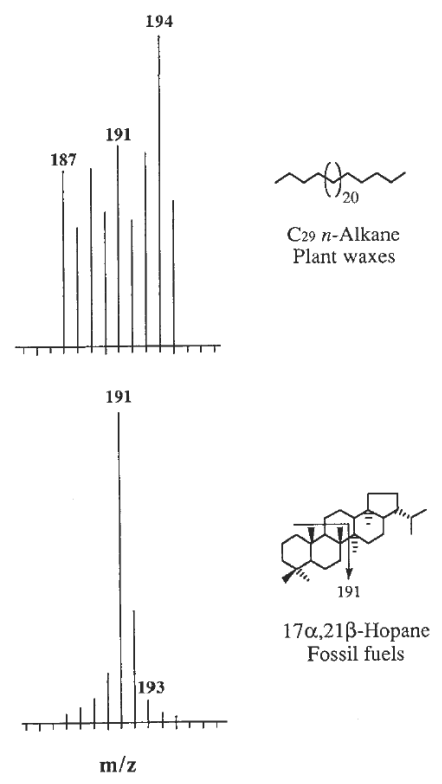

Figure 2. Mass spectra of plant wax $n$-alkane and fossil hopane from the highway pine, recorded by gas chromatography-mass spectrometry over the 187-195 amu range.

For Pinus nigra needles, the ion current at m/z 194 shows the typical fingerprint of plant waxes dominated by odd-numbered carbon $n$-alkanes [13] (Fig. 1). Several hopane homologues ranging from $\mathrm{C}_{27}$ to $\mathrm{C}_{34}$ were identified using ion current at $\mathrm{m} / \mathrm{z} 191$. All hopanes have the $17 \alpha, 21 \beta$ configuration found only in mature fossil fuels such as petroleum and deep sedimentary rocks [2,14-15]. Several molecular parameters based on hopane stereochemistry have been previously defined to measure the thermal maturity of sedimentary organic matter. For instance, the percentage ratios of Ts, 's' for 'stable', relative to Tm, ' $\mathrm{m}$ ' for maturable, and the percentage ratios of $22 \mathrm{~S}$ versus $22 \mathrm{R} \alpha \beta$-homohopanes (e.g. $\mathrm{C}_{31}$ ) increase with burial depth. For Pinus nigra, $\mathrm{Ts} / \mathrm{Tm}$ and S/R percentages are $56 \%$ and $58 \%$ respectively. Similar values were found for all plant species both in the highway-contaminated and suburb areas. They are typical of mature fossil fuels such as petroleum [12]. Moreover, two other chemical classes of molecular fossils, $\mathrm{C}_{27}-\mathrm{C}_{29}$ steranes and diasteranes bearing mature configurations (Fig. 3) were identified in all plant samples. These findings imply that ancient fuel products can be trapped on to the surface of plant waxes. Therefore, they could be used as molecular parameters of pollution as explained below. 

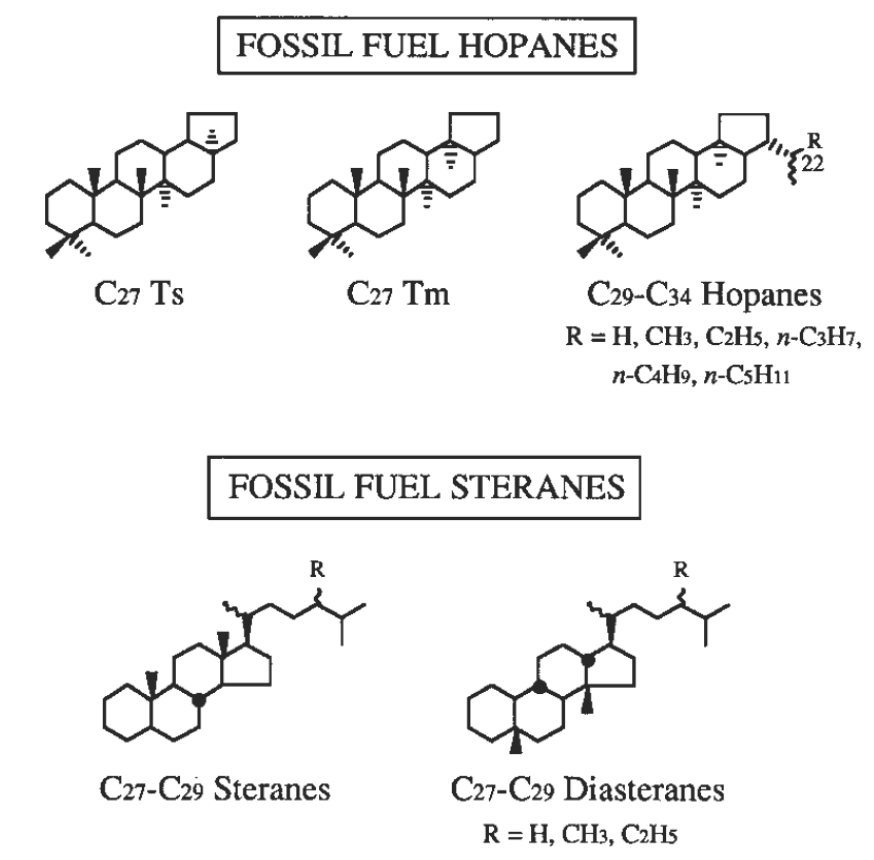

Figure 3. Molecular fossils identified in the highway pine waxes.

\section{Molecular pollution parameters}

Observation of ion currents at m/z 191 for Pinus nigra shows that the relative concentration of hopanes versus $n$-alkanes is higher for the highway-contaminated plant than for the suburb plant. We therefore defined two pollution parameters (PP) to measure the extent of fossil fuel input (see Fig. 1):

$$
\begin{gathered}
\mathrm{PP} 1=100 . \mathrm{Ts} /(\mathrm{Ts}+29) \\
\mathrm{PP} 2=100.30 \alpha \beta /(30 \alpha \beta+29)
\end{gathered}
$$

where Ts refers to fossil fuel $18 \alpha$-trisnorneohopane, 29 to plant wax $\mathrm{C}_{29} n$-alkane, and $30 \alpha \beta$ to fossil fuel $\mathrm{C}_{30} 17 \alpha, 21 \beta$-hopane (Fig. 3). Pollution parameters were calculated by peak area integration at $\mathrm{m} / \mathrm{z}$ 191. Values for PP1 and PP2 are significantly higher for the highway pine, $38 \%$ and $66 \%$ respectively, than for the suburb pine, $9 \%$ and $23 \%$ respectively. Such molecular parameters are thus promising, highly sensitive new tools which could be used to assess the impact of fossil fuel pollutants on the modern environment. Moreover, since a large part of food products are plant-derived and since food production is now a very complex process involving multiple pathways and transportation, then fossil fuel biomarkers may also help to establish relationships between food and a possible contaminated crop field. Further work is under way to apply molecular pollution parameters to various modern media. 


\section{REFERENCES}

[1] A. Van Dorsselaer, A. Ensminger, C. Spyckerelle, M. Dastillung, O. Sieskind, P. Arpino, P. Albrecht, G. Ourisson, P.W. Brooks, S.J. Gaskell, B.J. Kimble, R.P. Philp, J.R. Maxwell and G. Eglinton, Degraded and extended hopane derivatives $\left(\mathrm{C}_{27}\right.$ to $\left.\mathrm{C}_{35}\right)$ as ubiquitous geochemical markers. Tetrahedron Lett., 14 (1974) 1349-1352.

[2] A.S. Mackenzie, R.L. Patience, J.R. Maxwell, M. Vandenbroucke and B. Durand, Molecular parameters of maturation in the Toarcian shales, Paris Basin, France. I. Changes in the configurations of acyclic isoprenoid alkanes, steranes and triterpanes. Geochim. Cosmochim. Acta 44 (1980) 1709-1721.

[3] A.S. Mackenzie, S.C. Brassell, G. Eglinton and J.R. Maxwell, Chemical fossils: the geological fate of steroids. Science 217 (1982) 491-504.

[4] G. Ourisson and P. Albrecht, Hopanoids. 1. Geohopanoids: the most abundant natural products on earth? Acc. Chem. Res. 25 (1992), 398-402.

[5] M. Dastillung and P. Albrecht, Molecular test for oil pollution in surface sediments. Mar. Pollut. Bull. 7 (1976) 13-15.

[6] M. Rohmer, M. Dastillung and G. Ourisson, Hopanoids from $\mathrm{C}_{30}$ to $\mathrm{C}_{35}$ in recent muds. Naturwissenschaften 67 (1980) 456-458.

[7] B.R.T. Simoneit, Application of molecular marker analysis to reconcile sources of carbonaceous particulates in tropospheric aerosols. Sci. Tot. Environ. 36 (1984) 61-72.

[8] F.D. Hostettler, J.B. Rapp and K.A. Kvenvolden, Use of geochemical biomarkers in bottom sediment to track oil from a spill, San Francisco Bay, California. Mar. Pollut. Bull. 24 (1992) 1520. F.D. Hostettler, J.B. Rapp, K.A. Kvenvolden and S.N. Luoma, Organic markers as source discriminants and sediment transport indicators in south San Francisco Bay, California. Geochim. Cosmochim. Acta 53 (1989) 1563-1576.

[9] E. Lichtfouse, H. Budzinski, P. Garrigues and T.I. Eglinton, Ancient polycyclic aromatic hydrocarbons in modern soils: ${ }^{13} \mathrm{C},{ }^{14} \mathrm{C}$ and biomarker evidence. Org. Geochem. 26 (1997) 353359.

[10] P. Henner, C. Schwartz and E. Lichtfouse, Pipette Pasteur extraction: a fast, convenient, exhaustive and environmentally friendly method for the extraction of solid samples. Analusis 25 (1997) 51-52.

[11] E. Lichtfouse, P. Albrecht, F. Behar and J.M. Hayes, A molecular and isotopic study of the organic matter from the Paris Basin, France. Geochim. Cosmochim. Acta 58 (1994) 209-221. [12] K.E. Peters and J.M. Moldowan, The Biomarker Guide. Prentice Hall, Englewood Cliffs, 1993.

[13] G. Eglinton and R.J. Hamilton, Leaf epicuticular waxes. Science 156 (1967) 1322-1335. [14] W.K. Seifert, Steranes and terpanes in kerogen pyrolysis for correlation of oils and source rocks. Geochim. Cosmochim. Acta 42 (1978) 473-484.

[15] W.K. Seifert and J.M. Moldowan, Applications of steranes, terpanes and monoaromatics to the maturation, migration and source of crude oils. Geochim. Cosmochim. Acta 42 (1978) 77-95. 